\title{
Casting a Larger Net: Determinants of Managerial Networking in Public Organizations
}

\begin{abstract}
:
Managerial networking is an important part of public management. Research has forcefully demonstrated how this aspect of management directly and indirectly is related to organizational outcomes. Much less is known, however, about the determinants of managerial networking. This is especially true with regards to individual-level explanations. This paper addresses this important gap and proposes a composite model of managerial networking as formed by three sets of factors: personal, job-related, and organizational. On this background a set of hypotheses are developed and tested in a study of top-tier managers in Danish municipalities. Results suggest that managers engage in two different types of external networking, and that the amount of networking behavior is determined in a complex interplay of the three sets of explanatory factors. Contributions to existing research are discussed.
\end{abstract}




\section{INTRODUCTION}

Managers of public organizations are tasked with dealing with increasingly complex and unstable environments. As a consequence it is central for public organizations to employ managers with the ability to develop and nurture relations to a range of actors outside the organization. Such relations are multifaceted and involve buffering and bridging activities that seek to promote organizational interests. On this background it is not surprising that a substantial body of literature has focused on how managers of public organizations navigate a myriad of relations to different external actors. This type of managerial behavior has been coined 'managerial networking'. This concept takes as point of departure that managers of public organizations can and do manage the environment in order to further the interests of their organizations. Indeed, by now most research indicates that managerial networking is related to organizational performance (e.g. Meier \& O’Toole, 2001; 2003; Schalk, Torenvlied \& Allen, 2010). Typically using a measure of the frequency with which (top) managers are in contact with a range of different salient actors in their environments (Torenvlied et al., 2012), this line of studies demonstrate a relation between the amount of managerial networking and organizational outcomes. Managers may, however, also engage in networking for other reasons than to further the interests of their organization. For instance, some of the networking activity may be triggered by classical ceremonial obligations or be instrumental to enhance ones future career possibilities.

While the importance of managerial networking seems well established, research attention has recently shifted towards achieving a greater understanding of finer mechanism in the process. For instance, Walker, O’Toole \& Meier (2007) investigate how networking behavior differ between managers at different managerial levels, and Torenvlied et al. (2012) explore how the concept of managerial networking itself may consist of different sub-elements. Surprisingly little knowledge, however, still 
exist when it comes to characterizing why some managers engage in more, or different types of, networking behavior compared to others (Andrews et al. 2011). With managerial networking strongly linked to organizational performance this is an important gap in our current understanding of public management. Along these lines Torenvlied et al. (2012:17) call for future research to “... identify different types of managers, based on their networking activity on ... separate dimensions." This paper takes on this task and explores variation in managerial networking. We argue that in order to gain a deeper understanding of managerial networking it is important to take personal as well as organizational contingencies into account. On this background we develop and test a comprehensive theoretical model of managerial networking.

Even though research has explored a number of antecedents to general leadership styles (e.g. Barbuto, 2005; Hansen 2011; Yukl 2013) very little research has explicitly sought to identify sources of variation in managerial networking behavior. In a recent study Andrews et al. (2011) takes a first step in this direction by exploring environmental and organizational determinants of managerial networking. Other studies have investigated how the performance effects of networking is moderated by personal factors like gender (Meier, O’Toole \& Goerdel, 2006) and tenure (Juenke, 2005) but very few studies explicitly seek to explain networking behavior in itself. As existing research, especially when it comes to public organizations, is scarce we seek to further develop the understanding of managerial networking through an explicit focus on personal and job-related factors which to our knowledge have not previously been studied with relation to managerial networking in the public sector. We propose a model that posits managerial networking to be a function of personal, job-related, and organizational factors. We test the model using rich data on more than 600 managers in all Danish municipalities. 
With the study we make three important contributions to existing knowledge of managerial networking. First and most important, we offer a very comprehensive test of sources of variation in managerial networking. As argued above such an examination is long due. Because we are able to include a wide range of variables, we are able to assess and compare a range factors that theoretically is suggested to be related to networking behavior. We complement Andrews et al.'s (2011) recent study of environmental determinants of networking by getting closer to the actual networking behavior through a focus on personal and organizational factors. Second, as recently suggested by Torenvlied et al. (2012), we identify and distinguish between two dimensions of managerial networking. One dimension is relations to peers as well as other public sector entities. Relations to such actors may assist managers in coping with various challenges that are either shared or on which the organization is dependent on other public sector organizations. The second dimension is relations to local businesses and media on which managers and their organizations may rely for support. In our empirical analysis we investigate whether different types of managers place different emphasis in the relation to these two different types of networks. Third, most studies of managerial networking within public administration research is conducted in the education sector (see e.g. Meier \& O'Toole, 2001; 2003 in the US, and Torenvlied \& Akkerman, 2012 in the Netherlands). Arguably there is a need to extent this research into other parts of the public administration as well. This study complements Walker, O'Toole \& Meier (2007) with a focus on managers in traditional multi-purpose municipal entities, yet in a Danish context. 


\section{THEORY}

Delivering public sector services has always involved spanning a complex web of organizations and individuals. It has been argued that managing the network of inter-related actors has become increasingly important to most public organizations (Goldsmith \& Eggers, 2004). Rainey (2009) cites a variety of reasons that have spurred this trend including increased contracting of public services, greater use of co-production and involvement of non-profits, and (not least) the increased complexity and uncertainty surrounding many public service challenges that make them exceed the capacity of a single organization to solve. Against this backdrop, managing external relations is a ubiquitous part of public sector management.

Research has used different lenses to understand networks and network management in the public sector. One line of research has focused on understanding whole organizational networks. The main purpose of these studies has been to explore the mechanisms involved when organizations interact in delivering services and determining the antecedents of superior network performance (Agranoff \& McGuire, 2003). For instance, Provan and Milward (1995) studied the network of organizations involved in delivering mental health services in four urban areas. Besides facilitating public service delivery it has also been argued that networks may shape action by exposing members to selective learning and norms (Villadsen, 2011). A second line of research has zoomed in on the key actors involved in networking. While more narrowly scoped on the relational work of individual organizations this research has offered a more detailed understanding of the networking process and how it relates to organizational outcomes (Meier \& O’Toole, 2001). This research has not only convincingly reported a positive effect of managerial networking activity; it has also explored a number of interactions with other variables to understand the mechanisms involved. Results have for instance suggested that 
managerial networking is more effective when organizations have the capacity to support it (Meier \& O’Toole, 2010), and when managers are more experienced (Juenke, 2005). Importantly, it has also been suggested that the relation between networking and organizational performance is curvilinear such that the positive effects tampers off at some point indicating that managers must strike a balance between managing the external and internal aspects of the organization (Hicklin, Meier \& O’Toole, 2008). This paper builds on this second line of research and is interested in managerial networking behavior. Despite the strong indications of positive effects of networking surprisingly little research has focused on identifying key antecedents to explain networking behavior of public managers (but see Andrews et al. 2011). This is an important omission not only to our scholarly understanding of public management but also to organizations trying to blend the right mix of managerial quality in order to pursue desired outcomes.

As mentioned only little empirical knowledge exist that illuminate variation in managerial networking in public organizations. Thus we argue that more research is needed both in terms of broadening the variety of antecedents tested and in terms of expanding the scope of contexts in which managerial networking behavior is examined. In one of the few studies explicitly seeking to identify determinants of networking behavior Andrews et al. (2011) find that environmental demands along with organizational structure and strategy are related to more managerial networking behavior. This is an important contribution that underlines how networking behavior seems to be undertaken in response to organizational contingencies. Still, the study includes only variables at the organization and environment level, and includes no specific information about the managers performing the networking. An important next step therefore is to include such information in order to closer characterize the network managers (see Forret \& Dougherty, 2001). 
Some tentative results are reported in other studies. Juenke (2005) reports a negative relation between manager experience and tenure on networking behavior among Texas School district superintendents. This indicates that managerial networking is an evolutionary process where managers need to spend time early on in developing a large network. Meier, O’Toole \& Goerdel (2006) report no gender differences in external networking behavior using the same empirical setting. In a comprehensive study of English local government managers Walker, Meier \& O’Toole (2007) find that networking behavior seems to vary with managerial level. Taken together this research suggests a steadily increasing understanding of antecedents to networking behavior. What, however, appears to still be missing in the ongoing characterization of managerial networking is an explicit attention to personal and job-related factors as well as comprehensive investigation where such a focus is studied along with organizational factors in order to further isolate which factors are determinants of managerial networking and which are simply correlates of other factors. Such an investigation is crucial in order to test a multiplicity of explanations concurrently while controlling for possible confounding effects.

Based on the emerging knowledge described above it is likely that personal characteristics like education, experience and tenure as well as job-related characteristics such as managerial level and number of subordinates are related to involvement in networking behavior. We further argue that it is important to concurrently consider organizational factors in order to be able to isolate important antecedents.

We propose that in order to achieve a comprehensive understanding of managerial networking it is necessary to understand how managerial behavior is shaped by his or her former experiences as well as current job contingencies pertaining not only to narrow job related factors but also the wider 
organization. As these variables may not only be related to networking behavior but also themselves be interrelated it is important to consider them concurrently in order to gauge their individual impacts.

As described above, we focus on two different parts of managerial networking. Following Torenvlied et al. (2012) we distinguish between coping networking and support networking. The former is networking activity aimed at helping organizations cope with short and long run operative challenges. This type of networking involves interacting with peers in other public sector agencies to get access to information and knowledge. This may also involve direct collaborations about service execution. The other type of networking is related yet distinct. It involves cultivating relations that can help garner local support for decisions or for service delivery. In practice this type of networking takes place when public managers nurture relations to local business and media. Local businesses may help facilitate effective contracting while media relations help project positive images of the municipality and its work. We take Torenvlied et al.'s two concepts as our point of departure. While networking activity may be done for a number of reasons, it tends to be justified by the type of rationale provided by Torenvlied et al. The distinction resembles a well-known distinction from organizational institutionalism between the technical (coping networking) and institutional (support networking) environments of the organization (Meyer \& Scott 1992). As little research attention has been directed towards understanding differences between different types of networking behavior we take an exploratory stance and do not develop separate hypotheses for the two different types of managerial networking activity. Consequently, in the following section hypotheses will be developed linking different personal, job, and organizational factors to networking behavior in general. In the discussion section we will take up the question of whether and how it is possible and relevant to distinguish different types of networking managers. 


\section{Hypotheses}

Personal factors.

In order to understand differences in managers' networking behavior it is necessary initially to focus on the career of a given manager.

Dispositions towards networking behavior may be formed already at the educational level. Education is one of the most basic elements of human capital. Individuals who have received a higher educational degree have been exposed to more complex and abstract learning situations. While this training may not in itself involve networking skills, it does make individuals better equipped to understand and interpret the complexities of social and organizational life and the importance of attending to numerous interested actors in order to achieve personal or organizational success. Furthermore, higher education may be related to managerial networking as individuals with more education are awarded more strategic responsibility in top management teams.

Managers' networking behavior is likely to be further developed as their careers progress. Different lines of research have argued that individuals are profoundly affected by previous job experiences. The literature about executive migration argues that managers bring knowledge, values and assumptions when they migrate between different positions. This insight has explained why organizations are more likely to adopt practices that were present at a new manager's previous place of employment (Kraatz and Moore, 2002). Along these lines it has also been found that managers with previous employment outside the field of a new organization are more likely to carry out more profound organizational changes (Villadsen, 2012). Similarly, we may expect managerial networking to be affected by 
experience in other sectors or other parts of the public sector. Such experience may not only have helped mangers build a larger and more diverse network on which subsequently to draw, it may also have illuminated how delivery of municipal services can be importantly aided by connecting to diverse outside actors.

While education and diverse work experiences may be positively related to networking the opposite may be true for tenure. Juenke (2005) describes how tenure is related to managerial networking. He argues that over time a manager will gain knowledge and learn about the relevant network. As a consequence some amount of evolution will take place where managers will learn about which relations are more important and which are less important. This will help prioritize time on those relations from which most benefit can be accrued. In these relations trust will further develop. Based on this theory Juenke (2005) argues that while networks may become smaller over time managers' will be able to benefit more from them. Using data on Texas school district superintendents he finds general support for this theory. Along the same lines we expect tenure in the current position to be negatively related to managerial networking while acknowledging that these smaller networks may have better payoffs.

Elaborating on the argument suggested above it can be argued that it may not be tenure in the current position which is most important but general management experience. That is, even though a manager is new to a position he or she may have learned the tricks of the trade in previous managerial positions and focus on creating smaller yet qualitative useful networks. In order to gain a comprehensive understanding of the importance of experience this is an important addition.

In total, we suggest the following four hypotheses relating personal factors to managerial networking. 
Hypothesis 1: A higher educational degree will be positively related to frequency of managerial networking.

Hypothesis 2: Previous experience in either the private sector or the central state administration will be positively related to frequency of managerial networking.

Hypothesis 3: Tenure in the current position will be negatively related to frequency of managerial networking.

Hypothesis 4: Previous management experience will be negatively related to frequency of managerial networking.

\section{Job-related factors}

The distinction between person and position can sometimes be blurry. Next, we seek to further advance our theory of managerial networking by discussing two job-related factors, managerial level and the number of subordinates.

It has long been recognized that managers who occupy important roles in the organization are in better positions to engage in effective network relationships (Pfeffer, 1994; Mintzberg 1973). Managers who occupy higher positions are often expected to be involved in networking activities in order to promote the interests of the organizations either when it comes to creating or nurturing business deals or when they fulfill public relations purposes (Forret \& Dougherty, 2001). A few studies have explicitly examined this relation. Michael and Yukl (1993) found that higher level managers indeed engaged in more managerial networking. In two other studies results are more mixed. Forret and Dougherty (2001) 
found a general yet not unambiguously positive relation in a private sector setting. In their study of English local government managers Walker, Meier \& O’Toole (2007) also report somewhat mixed results relating managerial level to networking. While empirical evidence seems to be mixed, we rely on the classical arguments stating that higher level managers have more boundary spanning responsibilities to form a hypothesis for a positive relation.

Managerial level, however, may not be the only thing about a manager's job that shape networking behavior. As previously mentioned, managers must divide their time between internal and external activities (Hicklin, Meier \& O'Toole, 2008). This means that if jobs are designed such that internal management is challenging and or take up a substantial amount of time less time can be devoted to external networking. One way to assess the internal demands of the job is by looking at the number of subordinates a given manager is responsible for. This, of course, is correlated with managerial level but holding this factor constant substantial variation still exist in managerial demands to people management in Danish municipalities. Depending on organizational size as well as the division of responsibilities some managers are in charge of large areas with many employees while others are in charge of smaller ones. This leads us to formulate the following two hypotheses:

Hypothesis 5: A higher managerial level will be positively related to frequency of managerial networking.

Hypothesis 6: Responsibility for a larger number of subordinates is negatively related to frequency of managerial networking (controlling for managerial level).

\section{Organizational factors}


To gain a comprehensive understanding it is necessary also to consider organizational antecedents to managerial networking. It was recently suggested by Andrews et al. (2011) that key antecedents can be identified at the organizational level. On the structural side their results show that managers in organizations with low formalization and high specialization engage in more external networking. Their results pertaining to English local government managers also strongly suggested negative relations between the organizational strategies of defending and reacting and managerial networking. The objective of this section is to build on this previous knowledge to further our understanding on how organizational factors may be related to managerial networking. This is also necessary in order to be able to conduct a comprehensive test of the personal and job-related factors described above. Without concurrently examining these different explanations it is not possible to rule out spuriousness in our estimates of antecedents to managerial networking. Such spuriousness is indeed plausible as certain types of managers may be attracted to certain types of organizations thereby making it difficult to separate which explains variation in managerial networking.

To gain an understanding of how organizational factors may relate to managerial networking we focus on the importance of transnational organizational innovations often related to the New Public Management movement in Public Administration (Hood 1991; Dunleavy et al 2006; Hansen 2013, forthcoming). Market type organizational innovations like contracting to private providers, benchmarking, and use of internal contracts have found their way into the daily operations of many municipalities in Denmark (Hansen, 2011). As such practices are thought to heighten focus on core service delivery by putting in place a governance system based on market or quasi-market principles one could think that these practices would reduce the need for managerial networking. On the other hand, compelling arguments can be forwarded for why such practices may in fact increase the 
prevalence of managerial networking (Hansen, 2011). To facilitate the effective use of NPM practices there is a great need for managers that can span organizational boundaries in order to create effective relations to private providers as well as benchmarking. On the more informal level such practices may also increase the need of maintain relationships with peers with whom it is possible to discuss challenges as well as possibilities involved in the use of the practices.

Related to the use of market type NPM practices more and more public organizations are also employing management tools which where earlier mainly found in the private sector. Such tools include the use of quality systems, the balanced scorecard, and value based management. Again, as these tools have their focus on the internal side of the organization it may seem obvious to predict a negative relation to managerial networking which is external in nature. But as argued above the use of such tools may in fact make managerial networking even more important. Managers with responsibility in organizations that place importance on such management tools need external support and inspiration as well as access to informal information. To ensure that the right tools are in place and that they are calibrated towards achieving desired outcomes compared to other organizations effective external relationships are vital.

Finally, it can also be argued that causality may work in the opposite direction. Organizations with more networking managers are likely to be more exposed to NPM practices and management tools and thus facilitate diffusion (Hansen, 2011). Once the practices and tools are in place the managers may use the same relations to exchange experiences and gain new knowledge that can be used for improvements. In total we expect: 
Hypothesis 7: The use of transnational organizational innovations (such as management tools and NPM related organizational practices) is positively related to frequency of managerial networking.

\section{METHODS}

Setting and data collection. As stated above, a growing body of research has investigated managerial networking in public sector organizations. Part of the contribution that we aim to make with this paper involves scrutinizing the importance of variation in education, managerial levels, and work histories. Therefore, we choose to conduct our empirical analysis in a municipality setting which have the advantage of employing a rather diverse group of managers at different levels. Compared to most previous research which focuses on educational settings, our focus on municipalities precludes us from including clear performance measures as these are notoriously difficult to identify for multipurpose organizations.

We have chosen to use data from Danish municipalities. This is an excellent setting for this study as these are fairly homogenous entities conducting very similar tasks and sharing similar management structures. There are 98 municipalities which are in charge of a large part of the public services including schools, eldercare, child care, social welfare, most roads, libraries etc. The municipalities are led by an elected council but all have independent administrations in charge of the actual service provisions. Municipalities are typically headed by a city manager. At the next level a small number of directors are in charge of individual service areas. In each area these managers are supported by a few other top managers. These are the tiers of top managers that we are interested in in this study. 
To test the hypotheses forwarded above we conduct empirical analyses build on a survey from October-November 2008. With the objective of reaching the population of top-tier municipal managers the survey was distributed to the members of four Danish local government manager associations including almost all top tier municipal managers in Denmark: The association of Danish city managers, the association of Child- and culture managers (including primary school administration), The association of Technical service managers (including road constructing and city planning administration), and the association of social service managers (including eldercare administration). While membership of these associations is not mandatory it is very rare that managers are not members of these professional communities. The few non-members in the four top positions where also included in the survey. Among the 1105 members of the four associations $81.1 \%(n=896)$ have answered the survey. Including $75.5 \%(n=74)$ of the city managers, $82.7 \%(n=81)$ of the child- and culture managers, $71.4 \%(n=70)$ of the technical service managers and $76.5 \%(n=75)$ of the social service managers in Denmark. Additionally 168 other top civil servants with other administrative functions and 407 other local government managers responded to the survey participated. The study is fairly representative of the top tiers of local government managers in Denmark (Hansen, Jensen, and Pedersen 2009).

The data collection is subject to some of the ordinary caveats about survey data. First, self-reported data may be biased because respondents for a variety of reason do not answer questions truthfully. As almost all variables refer to actual factual information this problem should minimized in this study (Meier \& O'Toole, forthcoming). This is also true for our dependent variable, frequency of contact with a range of external actors, which Meier and O'Toole show can be measured relatively reliably using self-reported measures (2012). Of all the variables only the variable measuring the use of a range 
of NPM practices and management tools is based on a perception. All other variables relates to objective facts which in principle could be fact-checked (see description of variables below). Second, survey based studies will often be subject to questionable causality claims as variables are measured concurrently. As most explanatory variables relates to previous facts like education and work history, we do not consider this a major problem here (even though with this non-experimental setting we cannot entirely rule out endogeneity caused by omitted variables related to networking and for instance

education or specific work histories). Finally, single source bias may be a problem when most variables are collected in the same questionnaire. For the reasons stated above we do not consider this a major problem. To further ensure this, we conducted a Harman's one-factor test and found no indications of single source bias.

\section{Variables.}

Dependent variable. Our dependent variable is managerial networking. We follow a range of previous studies (see Meier \& O'Toole, 2001 and our citations above for more recent examples) to measure this by the frequency with which a manager interacts with a range of external actors. A five point scale was used reaching from "daily" to "rarely/never". We focus on interactions with a range of actors in municipalities immediate task environment including managers in other municipalities, the central government, and the professional association, as well as actors in the institutional environment (Scott and Davies, 2007) on which municipalities rely for support and legitimacy, namely the press and local businesses. As suggested in recent research (Torenvlied et al., 2012) we identified two factors with eigenvalues larger than 1 in the managers' responses as indicated in table 1 . 
Insert table 1 about here

The two factors correspond to two of the three factors that Torenvlied et al. (2012) find in their study of school district superintendents. We follow their labeling of the factors as coping networking and support networking. Coping networking is managerial networking targeted at actors which directly can help solve tasks in the municipality. These actors may either be collaborators or simply possess important knowledge or know-how that managers may demand. Support networking on the other hand is targeting actors which are important for the municipality but often not on a day-to-day basis. These actors, the local press and business leaders, may be very important to maintain good relations with as they can profoundly help (or obstruct) operations and projects.

\section{Independent variables.}

A range of independent variables are used in the study. Most are operationalized quite intuitively. They are all described in Table 2 below.

Insert table 2 about here

While the personal and job-related variables are quite straight forward some comments should attached to the organizational level variable. Hypothesis 7 expected the networking to increase with the use of 
NPM related practices and management tools in the organization. To measure this we utilize respondents' perceptions of the importance of a range of tools and practices in the organization. In total 11 practices where used. These include contracting, quality systems, balanced score card, lean, and value based management. As stated above, bias may be involved in peoples' perceptions of the use of organizational practices. To increase reliability we therefore conducted a factor analysis of the 11 practices. It turned out that the use of practices and tools where correlated to a substantial degree. Only one factor with an eigenvalue above 1 emerged (3.04). This factor was subsequently used in the analyses. This approach was also previously used by Hansen (2011).

Control variables. We include five control variables. On municipality level we control for size measured by number of inhabitants, tax base as a proxy for wealth, and service level which is a standardized measure of the composite service level calculated by the Ministry of the Interior. We also include to individual level factors, gender and age.

Estimation. We test our hypotheses using OLS regression. One concern is that the observations are not independent as each municipality contributes with multiple respondents. To account for this we report estimation with standard errors clustered by municipality. To ensure that multicollinearity was not a concern we calculated variance inflation factors for all models. With no values larger than 2.00, multicollinearity is indicated not to be problematic. 


\section{FINDINGS}

Descriptive statistics and correlations are reported in table 3 below.

Insert table 3 around here

The results of our hypotheses testing are reported in two tables. Recall that the dependent variable, managerial networking, was split in two distinct sub-elements. One element is concerning coping networking while the other is concerning support networking. While these two types of network activities arguably are related they also describe distinct dimensions of managerial networking. For this reason we present two separate sets of analyses. The first table concerns determinants of coping networking and can be found below.

Insert table 4 about here

In total five models are presented in the table. The first model includes only the five control variables. In the following three models personal (model 2), job-related (model 3), and organizational factors are entered sequentially. Model 5 presents a "full" model including all variables in the study. Because of missing values $\mathrm{n}$ varies between the models. 
Before presenting the individual results it is worth noting that each of the three partial models adds significantly to r-square. This indicates that each of the three sets of variables merit attention even though many have not explicitly been studied previously. It is also worth noting that model 5 adds significantly more to r-square than any of the partial models. This indicates that each of the three sets of explanatory factors contributes with some unique and non-overlapping explanatory power.

Moving to the results of the individual hypotheses tests we find a mixed picture where only some of the hypotheses are supported. Looking at the personal factors in model 2 there is preliminary support to the assertions that central government experience is positively related to networking while previous managerial experience is negatively related to networking. Contrary to our expectations an engineering degree is negatively related to coping networking. This may have to do with the fact that engineers are not trained specifically to positions in public administration and consequently find it hard to engage in a coping network with actors in other public agencies. There is marginal $(\mathrm{p}<0.1)$ support to the influence of professional training and experience from a larger number of other municipalities.

Interestingly the effects of engineering degree and central government experience become significantly smaller in model 5. This suggests that some degree of mediation is taking place and the effects of these personal factors in fact "work through" the job-related and organizational variables. This is conceivable as personal factors like these may lead managers to certain positions and types of organizations. We will elaborate on this in the subsequent discussion.

Regarding the position specific factor results are mixed. There is a strong and consistently positive effect of being city manager. This indicates that coping networking is performed more by higher level officials. On the other hand there is no effect concerning the number of subordinates. In model 4 and 5 
there is a similar strong and positive effect of being manager in an organization embracing a range of NPM related practices and management tools. In table 6 further below these results are summarized.

Insert table 5 around here

In table 5 above the results of regressions predicting the frequency of supporting networking by Danish municipality managers are presented. As with the estimations pertaining to coping networking, also here there is support to variables relating all three overall explanatory factors. Again, it is noteworthy that all models represent significant increases in r-square. The most significant increase happen with the introduction of the position-related factors in model 3 but to this further explanation is added by the other factors in the full model 5.

In model 2 there are positive effects of all three educational variables. This suggests that higher educational degree as well as professional supplementary education increases networking targeting business leaders and the press. As in the previous model we see clear signs of mediation. Specifically, the effects of social science degree and professional managerial training are both reduced in the full model when including other factors. This suggests that the educational effects are transmitted through positional and organizational factors. A similar pattern is found for managerial experience where an initially positive effect is washed away in model 5. Overall this lends partial support for the personal factors with regards to support networking. 
As was the case in model 4 substantially more consistent results are found when it comes to job-related and organizational variables. Again there is a positive and significant effect of occupying the very top position as city manager. However, it is also indicated that the tier-two managers, the sector directors, are more likely than lower level managers to engage in a higher frequency of support networking. Also in line with table 4 there is a strong positive effect of a higher importance placed on NPM practices and management tools in the organization.

In table 6 the results are summarized with regards to the individual hypotheses.

Insert table 6 around here

Overall there is support for including each of the three explanatory factors in the model. Results, however, vary more when we go into the individual variables and the different dimensions of networking. This is especially true for the personal factors while the job-related and organizational variables show a more consistent picture. Below we will discuss these results in further detail.

A few of the control variables are worth mentioning. There is some indication that age is negative related to coping networking. This, however, does not seem to be the case regarding support networking. In a separate analysis we entered age squared to investigate any possible non-linearities. This squared term did not reach significance in any of the models. More interestingly there is a consistent effect indicating that male managers engage in more external networking than female 
managers. While this is not our direct interest here, this result clearly suggests that more research into gender and networking may be needed.

\section{DISCUSSION}

Understanding the role of inter-organizational relations, networks, has been a central challenge to much recent research into public management. Researchers have forcefully demonstrated how and when managerial networking behavior is associated with better organizational outcomes. Little research, however, has explored the determinants of managerial networking in public sector organizations. This is an important neglect. While research has increased our understanding of antecedent to general leadership behavior (Hansen 2011; Yukl 2013), despite its apparent importance we still know only very little about the factors that shape and spur managerial networking. The objective of this study has been to address this gap. We have done so with a focus on two different types of networking behavior. Initially we will discuss our findings as they relate to our hypotheses as summarized in table 6. Subsequently, we will provide a broader discussion of the possible theoretical and practical implications of our findings as well as the limitations of our approach.

In hypothesis 1 we posited that a higher educational degree would be positively related to frequency of managerial networking and we tested it by means of two variables - a degree in social science and a degree in engineering. In terms of engineering we found that it was negatively related to coping networking (but not significantly so in model 5) and positively related to supporting networking. This may have to do with the fact that engineers, contrary to most other municipal top civil servants, have a substantial part of their work experience in the private sector (Hansen, Opstrup and Villadsen, 2013 
forthcoming), and that the technical services they usually manage include contracts with a number of private providers. Interestingly the effects of social science degrees as well as the negative effect of engineering degrees diminish when other factors are included in the estimations. This indicate that mediation is taking place and that certain educational profiles are attracted to certain positions and types of organizations which in turn are associated with more managerial networking.

With regards to work backgrounds we find only limited indications that this shapes managerial networking as expected in hypothesis 2 . Results suggest that previous experience in central government is related to more coping networking. This is not surprising as such a background may have helped create a network but also exposed individuals to knowledge about how municipalities may benefit from relations to government. While hypothesis 3 about tenure was not supported, the analysis provided some support for hypothesis 4 and the effect of managerial experience. As hypothesized, experience is indicated to substitute for coping networking. Once managers become familiar with the exigencies of a public management position they need not spend as much time nurturing external relations. This is in line with the previous findings that managerial networking becomes a quantitatively smaller part of the job as tenure increases but managers may by qualitatively better at exploiting a smaller set of relations (Juenke, 2005).

Another set of variables concerned job related factors. As also suggested by Walker, O’Toole and Meier (2007) we find that where you are in the hierarchy matter for your networking behavior. Our results clearly indicate that city managers engage in more networking (of both types) compared to lower level managers as suggested in hypothesis 5 . Their position provides them with a platform for building and maintaining external relations with a variety of collaborators and stakeholders. We did 
not, however, as suggested in hypothesis 6 find that the number of subordinates mattered for external networking.

Finally, hypothesis 7 suggested that the use of transnational organizational innovations in form of NPM inspired management tools and practices would be positively related to networking. We tested this using an index of 11 different organizational practices. We find strong support for this assertion regarding both types of managerial networking. This finding elaborates the findings by Andrews et al (2011) in English local governments. They find that networking is more pronounced when organizations do not pursue defender or reactor strategies. Implementing transnational innovations with inspiration from private sector settings indeed indicates that organizations take a more pro-active stance and seek to actively define and control their operations.

\section{Implications}

This study has shed new light on the determinants of managerial networking. By including three different sets of factors we have illuminated how networking behavior is shaped in the cross-section of personal factors like education and experience, characteristics of the positions, and organizational practices. Only few studies have explicitly sought to identify determinants of networking and none to our knowledge have included a detailed list of individual level characteristics. Most directly the study complements Andrews et al.'s study of environmental and organizational sources of networking with a focus on the networker him/herself.

Three more detailed implications of the study are worth highlighting. First, the results indicate how some of the personal factors are mediated by organizational and job related factors. This indicates that managerial networking is formed in a complex and dynamic interaction of a range of influences. 
Managers at different levels and in different types of organizations engage in different amounts of networking behavior. To make sense of this, it is important to go a step further back and see how different personal profiles seem to feed into types of jobs and organizations.

Second, the study distinguishes between two types of managerial networking. In a recent study Torenvlied et al. argue for the multidimensionality of managerial networking and identify three distinct dimensions. Of these three we identify the two, support and coping networking, in our study of Danish municipality managers. The third dimension relates to co-production and may be more relevant for school managers as Torenvlied et al. study than for general managers in large multi-purpose organizations. Future research of comparable nature could investigate this speculation in more detail. With this limitation noted, the fact that our study distinguishes two different types of managerial networking represents a distinct contribution as we can take a first step into 'profiling' different types of network managers. Generally our analyses of support networking have more explanatory power than those of coping networking. Personal factors like education and experience as well as position in the hierarchy are apparently better explanatory factors of this type of networking. This makes sense as coping networking has to do with day-to-day challenges and managers, no matter their profile, may sometimes be forced into networking in order to deal with pressing requirements. On the other hand may support networking be easier to engage in or abstain from per one's own desire. Aside from this it is interesting that results for hierarchical level and the use of innovative organizational practices are remarkably consistent and similar across the two types of networking. Future research should further investigate how different types of managers may engage in different types of networking.

Third, as discussed above our study corroborates and extends findings of recent research into a new national and organizational context. While this may appear like a trivial contribution, we consider this 
important in the collective effort to build more solid knowledge about public sector management. While we have introduced new variables to the study of networking behavior, the results have also amplified the importance of organizational factors as well as managerial level and tenure which was highlighted in previous research (Andrews et al., 2011; Juenke, 2005; Walker, O’Toole and Meier, 2007). This study has suggested that these variables indeed have independent effects when studied together and concurrently with a range of other factors.

\section{Limitations}

Like any other study there are some limitations which should be noted. As mentioned earlier the use of self-reported measures can always be questioned. While we are confident that the use of "fact-based" questions reduces this problem it cannot be ruled out.

A second limitation may be the empirical setting that we use. While we consider it a strength to use a general public management setting like municipality leadership it also poses some challenges. For instance the job specifications of managers in different municipalities may be less comparable than, say, for instance those of school leaders'. As Danish municipalities are very homogeneous these challenges should however be minimal. Finally, endogeneity should be noted as a limitation of a nonexperimental study like this. While this is no different from other studies of managerial networking we cannot rule out that some unobserved variables are related to both dependent and independent variables in the study. 


\section{CONCLUSION}

Research in public management has for long been interested in the importance of managerial networking. Using a comprehensive data set of top-tier managers in Danish municipalities this study has provided new insights about the determinants of managerial networking. Especially, it has been documented how a range of individual level factors contribute to the formation of managerial networking behavior. While extant research has linked such behavior to organizational outcomes the time is ripe for increasing attention to the public managers themselves and what forms their networking activity. We hope future studies will further illuminate this important aspect of public management. 


\section{REFERENCES}

Agranoff, R., \& McGuire, M. 2003. Big questions in public network management research. Journal of public administration research and theory, 13(3): 295-326.

Andrews, R., Boyne, G. A., Meier, K. J., O'Toole, L. J., \& Walker, R. M. 2011. Environmental and organizational determinants of external networking. The American Review of Public Administration, 41(4): 355-374.

Barbuto Jr, J. E. 2005. Motivation and transactional, charismatic, and transformational leadership: A test of antecedents. Journal of Leadership \& Organizational Studies, 11(4): 26-40.

Dunleavy, P., H. Margetts, S. Bastow, and J. Tinkler. 2006. New public management is dead - long live digital-era governance. Journal of Public Administration Research and Theory. 16:467-494.

Forret, M. L., \& Dougherty, T. W. 2001. Correlates of networking behavior for managerial and professional employees. Group \& Organization Management, 26(3): 283-311.

Goldsmith, S., \& Eggers, W. D. 2004. Governing by network: The new shape of the public sector. Washington, D.C.: Brookings Institution Press.

Hansen, M. B. 2010. Motivation og ledelsesorientering blandt kommunale topchefer - gør køn en forskel? Politica 42:459-477.

Hansen, M. B. 2011. Antecedents of Organizational Innovation. The Diffusion of New Public Management into Danish Local Government. Public Administration 89:285-306.

Hansen, M. B. 2013 forthcoming. Organisatorisk Innovation i den offentlige sektor. Politica 45.

Hansen, M. B., N. Opstrup, and A. R. Villadsen. 2013 forthcoming. En administrativ elite under forandring. Udviklingen i danske kommunale topchefers kollektive profil fra 1970 til 2008. Politica 45.

Hood, C. 1991. A Public Management for All Seasons. Public Administration 69:3-19.

Hicklin, A., O'Toole, L. J., \& Meier, K. J. 2008. Serpents in the sand: Managerial networking and nonlinear influences on organizational performance. Journal of Public Administration Research and Theory, 18(2): 253-273.

Juenke, E. G. 2005. Management tenure and network time: How experience affects bureaucratic dynamics. Journal of Public Administration Research and Theory, 15(1): 113-131.

Kraatz, M. S., \& Moore, J. H. 2002. Executive migration and institutional change. Academy of Management Journal, 45(1): 120-143. 
Meier, K. J., \& O'Toole Jr, L. J. 2001. Managerial strategies and behavior in networks: A model with evidence from US public education. Journal of Public Administration Research and Theory, 11(3): 271.

Meier, K. J., \& O'Toole Jr, L. J. 2003. Public management and educational performance: The impact of managerial networking. Public administration review: 689-699.

Meier, K. J., \& O'Toole JR, L. J. 2010. Beware of managers not bearing gifts: How management capacity augments the impact of managerial networking. Public Administration, 88(4): 1025-1044.

Meier, K.J.\& O’Toole, L.J. forthcoming. Subjective Organizational Performance and Measurement Error: Common Source Bias and Spurious Relationships. Journal of Public Administration Research and Theory

Meier, K. J., O'Toole Jr, L. J., \& Goerdel, H. T. 2006. Management activity and program performance: Gender as management capital. Public administration review, 66(1): 24-36.

Meyer, John W. and W. Richard Scott. 1992. Organizational Environments. Ritual and Rationality. Newbury Park: SAGE Publications, Inc.

Michael, J., \& Yukl, G. 1993. Managerial level and subunit function as determinants of networking behavior in organizations. Group \& organization management, 18(3): 328-351.

Mintzberg, Henry. 1973. The Nature of Managerial Work. London: Prentice-Hall, Inc.

Pfeffer, J. 1994. Managing with power: Politics and influence in organizations. Cambridge, MA: Harvard Business Press.

Provan, K. G., \& Milward, H. B. 1995. A preliminary theory of interorganizational network effectiveness: A comparative study of four community mental health systems. Administrative Science Quarterly, 40(1).

Rainey, H. G. 2009. Understanding and managing public organizationsJossey-Bass.

Schalk, J., Torenvlied, R., \& Allen, J. forthcoming. Network embeddedness and public agency performance: The strength of strong ties in dutch higher education. Journal of Public Administration Research and Theory.

Scott, W. R., \& Davis, G. F. 2007. Organizations and organizing : Rational, natural, and open systems perspectives (1st ed.). Upper Saddle River, N.J.: Pearson Education, Inc.

Torenvlied, R., \& Akkerman, A. 2012. Effects of managers' work motivation and networking activity on their reported levels of external red tape. Journal of Public Administration Research and Theory, 22(3): 445-471. 
Torenvlied, R., Akkerman, A., Meier, K. J., \& O'Toole Jr, L. J. 2012. The multiple dimensions of managerial networking. The American Review of Public Administration.

Villadsen, A. R. 2011. Structural embeddedness of political top executives as explanation of policy isomorphism. Journal of Public Administration Research and Theory, 21(4): 573-599.

Villadsen, A. R. 2012. New executives from inside or outside? the effect of executive replacement on organizational change. Public administration review.

Walker, R. M., O'TOOLE, L. J., \& Meier, K. J. 2007. It's where you are that matters: The networking behaviour of english local government officers. Public administration, 85(3): 739-756.

Yukl, G. 2013. Leadership in Organizations. Upper Saddle River, New Jersey: Pearson Prentice Hall. 
TABLE 1: Factor Analysis - Dimensions of Managerial Netoworking

\begin{tabular}{lllll}
\hline Items & $\begin{array}{l}\text { Factor } \\
\text { Score 1 }\end{array}$ & $\begin{array}{l}\text { Factor } \\
\text { Score 2 }\end{array}$ & Variable & Alpha \\
\hline How often are you in contact with.... & & & & \\
City managers from other municipalities & 0.53 & 0.36 & & \\
Employees in other municipalities & 0.45 & 0.15 & & \\
Employees at county level & 0.47 & 0.20 & Coping & 0.66 \\
& & & Networking & \\
Employees in central government & 0.49 & 0.18 & & \\
$\begin{array}{l}\text { Representatives from Municipalities } \\
\text { Denmark }\end{array}$ & 0.50 & 0.24 & & \\
Journalists & 0.21 & 0.62 & Support & 0.67 \\
& & & Networking & \\
Local Business Leaders & 0.15 & 0.62 & & \\
\hline
\end{tabular}

Note: Orthogonal rotation used. 
TABLE 2: Variables in the Analyses

\begin{tabular}{|c|c|}
\hline Variables & Measurement \\
\hline \multicolumn{2}{|l|}{ Controls } \\
\hline Population (In) & Population of municipality \\
\hline Tax base & Tax base per capita \\
\hline Service level & Index of service level calculated by Ministry of the Interior \\
\hline Age & Age of respondent \\
\hline Gender & Gender of respondent \\
\hline \multicolumn{2}{|l|}{$\underline{\text { Personal Factors }}$} \\
\hline Social Science Education & University degree in social science \\
\hline Engineering Education & University degree in engineering \\
\hline Professional Training & Professional training (MPA etc.) \\
\hline Central Government Experience & Previous work experience in central government \\
\hline & Previous work experience in the private sector \\
\hline $\begin{array}{l}\text { \# of municipalities previously employed } \\
\text { in }\end{array}$ & Number of municipalities in which respondents has previously worked \\
\hline Management Experience & Manger in previous job \\
\hline Tenure & Number of years in current job \\
\hline \multicolumn{2}{|l|}{$\underline{\text { Job-related Factors }}$} \\
\hline Municipal city manager & Dummy variable indicating city manager position \\
\hline Sector Director & $\begin{array}{l}\text { Dummy variable indicating position below city manager in charge of } \\
\text { specific area (tier-2) }\end{array}$ \\
\hline \# Subordinates & Number of sub-ordinates that respondent is responsible for. \\
\hline \multicolumn{2}{|l|}{ Organizational Factors } \\
\hline Organizational Innovation Index & $\begin{array}{l}\text { Index of the use the following practices and tools: Contracting, Order- } \\
\text { Execution-Model, Internal contracts, Free choice for clients, Mgmt by } \\
\text { objectives, Benchmarking, Quality systems, Balanced scorecard, Pay-for- } \\
\text { performance, Lean mgmt., Value-based mgmt. (Alpha }=0.80 \text { ) }\end{array}$ \\
\hline
\end{tabular}


TABLE 4: Regressions predicting frequency of coping networking

\begin{tabular}{|c|c|c|c|c|c|}
\hline & Model 1 & Model 2 & Model 3 & Model 4 & Model 5 \\
\hline \multicolumn{6}{|l|}{ Controls } \\
\hline \multirow[t]{2}{*}{ Population (In) } & -0.02 & -0.01 & 0.00 & -0.05 & -0.02 \\
\hline & $(0.05)$ & $(0.05)$ & $(0.04)$ & $(0.05)$ & $(0.05)$ \\
\hline \multirow[t]{2}{*}{ Tax base } & 0.00 & 0.00 & 0.00 & 0.00 & 0.00 \\
\hline & $(0.00)$ & $(0.00)$ & $(0.00)$ & $(0.00)$ & $(0.00)$ \\
\hline \multirow[t]{2}{*}{ Service level } & -0.67 & -0.80 & -0.65 & -0.75 & -0.92 \\
\hline & $(0.56)$ & $(0.57)$ & $(0.59)$ & $(0.59)$ & $(0.64)$ \\
\hline \multirow[t]{2}{*}{ Age } & $-0.01 *$ & -0.01 & -0.01 & $-0.01 * *$ & $-0.02 * *$ \\
\hline & $(0.00)$ & $(0.00)$ & $(0.00)$ & $(0.00)$ & $(0.00)$ \\
\hline \multirow[t]{2}{*}{ Gender } & $-0.20 * *$ & $-0.23 * * *$ & $-0.13^{*}$ & $-0.22 * * *$ & $-0.18^{* *}$ \\
\hline & $(0.06)$ & $(0.06)$ & $(0.06)$ & $(0.06)$ & $(0.06)$ \\
\hline \multicolumn{6}{|l|}{ Personal Factors } \\
\hline \multirow[t]{2}{*}{ Social Science Education } & & 0.03 & & & -0.09 \\
\hline & & $(0.07)$ & & & $(0.08)$ \\
\hline \multirow[t]{2}{*}{ Engineering Education } & & $-0.15^{*}$ & & & $-0.12+$ \\
\hline & & $(0.08)$ & & & $(0.08)$ \\
\hline \multirow[t]{2}{*}{ Professional Training } & & $0.09+$ & & & 0.05 \\
\hline & & $(0.06)$ & & & $(0.06)$ \\
\hline \multirow[t]{2}{*}{ Central Government Experience } & & $0.21 *$ & & & $0.21+$ \\
\hline & & $(0.10)$ & & & $(0.11)$ \\
\hline \multirow[t]{2}{*}{ Private Sector Experience } & & 0.05 & & & 0.03 \\
\hline & & $(0.08)$ & & & $(0.08)$ \\
\hline \multirow[t]{2}{*}{$\begin{array}{l}\text { \# of municipalities previously } \\
\text { employed in }\end{array}$} & & $0.03+$ & & & 0.02 \\
\hline & & $(0.02)$ & & & $(0.02)$ \\
\hline \multirow[t]{2}{*}{ Management Experience } & & $-0.15^{*}$ & & & $-0.21 * *$ \\
\hline & & $(0.06)$ & & & $(0.06)$ \\
\hline \multirow[t]{2}{*}{ Tenure } & & 0.00 & & & 0.01 \\
\hline & & $(0.00)$ & & & $(0.01)$ \\
\hline \multicolumn{6}{|l|}{ Job-related Factors } \\
\hline \multirow[t]{2}{*}{ Municipal city manager } & & & $0.60 * * *$ & & $0.58^{* * *}$ \\
\hline & & & $(0.13)$ & & $(0.15)$ \\
\hline \multirow[t]{2}{*}{ Sector Director } & & & 0.06 & & 0.04 \\
\hline & & & $(0.05)$ & & $(0.07)$ \\
\hline \multirow[t]{2}{*}{ \# Subordinates } & & & 0.00 & & -0.00 \\
\hline & & & $(0.00)$ & & $(0.00)$ \\
\hline \multicolumn{6}{|l|}{ Organizational Factors } \\
\hline Organizational Innovation Index & & & & $0.12^{* * *}$ & $0.11^{* *}$ \\
\hline
\end{tabular}




\begin{tabular}{llllll}
\hline & & & & $(0.03)$ & $(0.03)$ \\
Constant & 1.24 & 1.30 & 0.88 & 1.52 & 1.48 \\
$\mathrm{~N}$ & $(0.93)$ & $(0.99)$ & $(0.92)$ & $(0.95)$ & $(1.04)$ \\
R-square & 738 & 730 & 715 & 644 & 618 \\
$\Delta$ R-square (compared to model 1) & 0.02 & 0.05 & 0.06 & 0.05 & 0.12 \\
& & 0.03 & 0.04 & 0.03 & 0.10
\end{tabular}

$\left.\left.\left.\left.{ }^{* * *}\right) \mathrm{p}<0.001 ;{ }^{* *}\right) \mathrm{p}<0.01 ;{ }^{*}\right) \mathrm{p}<0.5 ;+\right) \mathrm{p}<0.1$

Municipality-clustered standard errors in parentheses 
TABLE 5: Regressions predicting frequency of support networking

\begin{tabular}{|c|c|c|c|c|c|}
\hline & Model 1 & Model 2 & Model 3 & Model 4 & Model 5 \\
\hline \multicolumn{6}{|l|}{ Controls } \\
\hline \multirow[t]{2}{*}{ Population (In) } & $0.08 * *$ & $0.08^{*}$ & $0.12 * * *$ & $0.06+$ & $0.10^{* *}$ \\
\hline & $(0.03)$ & $(0.03)$ & $(0.03)$ & $(0.04)$ & $(0.04)$ \\
\hline \multirow[t]{2}{*}{ Tax base } & -0.00 & $-0.00 *$ & $-0.00+$ & $-0.00 * * *$ & $-0.00 * * *$ \\
\hline & $(0.00)$ & $(0.00)$ & $(0.00)$ & $(0.00)$ & $(0.00)$ \\
\hline \multirow[t]{2}{*}{ Service level } & -0.69 & -0.49 & -0.78 & -0.33 & -0.47 \\
\hline & $(0.50)$ & $(0.53)$ & $(0.51)$ & $(0.55)$ & $(0.55)$ \\
\hline \multirow[t]{2}{*}{ Age } & -0.00 & -0.00 & -0.00 & $-0.01+$ & -0.01 \\
\hline & $(0.00)$ & $(0.00)$ & $(0.00)$ & $(0.00)$ & $(0.00)$ \\
\hline \multirow[t]{2}{*}{ Gender } & $-0.45 * * *$ & $-0.40 * * *$ & $-0.33 * * *$ & $-0.44 * * *$ & $-0.29 * * *$ \\
\hline & $(0.05)$ & $(0.05)$ & $(0.05)$ & $(0.05)$ & $(0.05)$ \\
\hline \multicolumn{6}{|l|}{ Personal Factors } \\
\hline \multirow[t]{2}{*}{ Social Science Education } & & $0.18^{* *}$ & & & -0.04 \\
\hline & & $(0.06)$ & & & $(0.07)$ \\
\hline \multirow[t]{2}{*}{ Engineering Education } & & $0.39 * * *$ & & & $0.42 * * *$ \\
\hline & & $(0.09)$ & & & $(0.08)$ \\
\hline \multirow[t]{2}{*}{ Professional Training } & & $0.13^{*}$ & & & $0.08+$ \\
\hline & & $(0.06)$ & & & $(0.06)$ \\
\hline \multirow[t]{2}{*}{ Central Government Experience } & & 0.10 & & & -0.04 \\
\hline & & $(0.09)$ & & & $(0.10)$ \\
\hline \multirow[t]{2}{*}{ Private Sector Experience } & & 0.06 & & & 0.06 \\
\hline & & $(0.08)$ & & & $(0.07)$ \\
\hline \multicolumn{6}{|l|}{ \# of municipalities previously } \\
\hline \multirow[t]{2}{*}{ employed in } & & $0.03+$ & & & 0.00 \\
\hline & & $(0.02)$ & & & $(0.02)$ \\
\hline \multirow[t]{2}{*}{ Management Experience } & & $0.10 *$ & & & -0.04 \\
\hline & & $(0.05)$ & & & $(0.05)$ \\
\hline \multirow[t]{2}{*}{ Tenure } & & 0.00 & & & -0.00 \\
\hline & & $(0.00)$ & & & $(0.00)$ \\
\hline \multicolumn{6}{|l|}{ Job-related Factors } \\
\hline \multirow[t]{2}{*}{ Municipal city manager } & & & $1.00 * * *$ & & $1.03 * * *$ \\
\hline & & & $(0.11)$ & & $(0.14)$ \\
\hline \multirow[t]{2}{*}{ Sector Director } & & & $0.37 * * *$ & & $0.38 * * *$ \\
\hline & & & $(0.04)$ & & $(0.05)$ \\
\hline \multirow[t]{2}{*}{ \# Subordinates } & & & 0.00 & & 0.00 \\
\hline & & & $(0.00)$ & & $(0.00)$ \\
\hline \multicolumn{6}{|l|}{ Organizational Factors } \\
\hline \multirow[t]{2}{*}{ Organizational Innovation Index } & & & & $0.16^{* * *}$ & $0.08 * *$ \\
\hline & & & & $(0.03)$ & $(0.03)$ \\
\hline Constant & 0.45 & -0.10 & -0.11 & 0.05 & -0.43 \\
\hline
\end{tabular}




\begin{tabular}{llllll}
\hline & $(0.67)$ & $(0.74)$ & $(0.69)$ & $(0.80)$ & $(0.84)$ \\
$\mathrm{N}$ & 738 & 730 & 715 & 644 & 618 \\
R-square & 0.10 & 0.15 & 0.26 & 0.14 & 0.33 \\
$\Delta$ R-square (compared to model 1) & & 0.05 & 0.16 & 0.04 & 0.23
\end{tabular}

$\left.\left.\left.\left.{ }^{* * *}\right) \mathrm{p}<0.001 ;{ }^{* *}\right) \mathrm{p}<0.01 ;{ }^{*}\right) \mathrm{p}<0.5 ;+\right) \mathrm{p}<0.1$

Municipality-clustered standard errors in parentheses 
Table 6: Findings compared to hypotheses (based on full model (Model 5))

\begin{tabular}{|c|c|c|c|}
\hline Hypotheses & $\begin{array}{l}\text { Findings } \\
\text { coping }\end{array}$ & $\begin{array}{l}\text { Findings } \\
\text { supporting }\end{array}$ & Conclusion \\
\hline $\begin{array}{l}\text { H1: A higher educational degree will be } \\
\text { positively related to frequency of managerial } \\
\text { networking }\end{array}$ & $\begin{array}{l}\text { No } \\
\text { significant } \\
\text { relation }\end{array}$ & $\begin{array}{l}\text { Partly } \\
\text { supported } \\
\text { (engineering } \\
\text { not social } \\
\text { science) }\end{array}$ & $\begin{array}{l}\text { Partly } \\
\text { supported }\end{array}$ \\
\hline $\begin{array}{l}\text { H2: Previous experience in either the private } \\
\text { sector or the central state administration will be } \\
\text { positively related to frequency of managerial } \\
\text { networking }\end{array}$ & $\begin{array}{l}\text { No } \\
\text { significant } \\
\text { relation }\end{array}$ & $\begin{array}{l}\text { No } \\
\text { significant } \\
\text { relation }\end{array}$ & Rejected \\
\hline $\begin{array}{l}\text { H3: Tenure in the current position will be } \\
\text { negatively related to frequency of managerial } \\
\text { networking }\end{array}$ & $\begin{array}{l}\text { No } \\
\text { significant } \\
\text { relation }\end{array}$ & $\begin{array}{l}\text { No } \\
\text { significant } \\
\text { relation }\end{array}$ & Rejected \\
\hline $\begin{array}{l}\text { H4: Previous management experience will be } \\
\text { negatively related to frequency of managerial } \\
\text { networking }\end{array}$ & Confirmed & $\begin{array}{l}\text { No } \\
\text { significant } \\
\text { relation }\end{array}$ & $\begin{array}{l}\text { Partly } \\
\text { supported }\end{array}$ \\
\hline $\begin{array}{l}\text { H5: A higher managerial level will be positively } \\
\text { related to frequency of managerial networking }\end{array}$ & Confirmed & Confirmed & Supported \\
\hline $\begin{array}{l}\text { H6: Responsibility for a larger number of } \\
\text { subordinates is negatively related to frequency } \\
\text { of managerial networking (controlling for } \\
\text { managerial level) }\end{array}$ & $\begin{array}{l}\text { No } \\
\text { significant } \\
\text { relation }\end{array}$ & $\begin{array}{l}\text { No } \\
\text { significant } \\
\text { relation }\end{array}$ & Rejected \\
\hline $\begin{array}{l}\mathrm{H7} \text { : The use of transnational organizational } \\
\text { innovations is positively related to frequency of } \\
\text { managerial networking }\end{array}$ & Confirmed & Confirmed & Supported \\
\hline
\end{tabular}


TABLE 3: Correlations

\begin{tabular}{|c|c|c|c|c|c|c|c|c|c|c|c|c|c|c|c|c|c|c|c|c|}
\hline & & 1 & 2 & 3 & 4 & 5 & 6 & 7 & 8 & 9 & 10 & 11 & 12 & 13 & 14 & 15 & 16 & 17 & 18 & 19 \\
\hline 1 & \begin{tabular}{|l|} 
Coping \\
Networking \\
\end{tabular} & 1 & & & & & & & & & & & & & & & & & & \\
\hline 2 & \begin{tabular}{|l|} 
Support \\
Networking \\
\end{tabular} & $0.3708^{*}$ & 1 & & & & & & & & & & & & & & & & & \\
\hline 3 & $\begin{array}{l}\text { Population } \\
\text { (In) } \\
\end{array}$ & 0.0016 & $0.0989^{*}$ & 1 & & & & & & & & & & & & & & & & \\
\hline 4 & Tax base & -0.0030 & $-0.0958^{*}$ & -0.0359 & 1 & & & & & & & & & & & & & & & \\
\hline 5 & Service Level & -0.0408 & $-0.1061^{*}$ & $-0.2806^{*}$ & $0.3614^{*}$ & 1 & & & & & & & & & & & & & & \\
\hline 6 & Age & -0.0463 & -0.0083 & -0.0636 & -0.0526 & -0.0184 & 1 & & & & & & & & & & & & & \\
\hline 7 & Gender & $-0.1226^{*}$ & $-0.2831 *$ & -0.0192 & 0.0277 & 0.0641 & $-0.1373^{*}$ & 1 & & & & & & & & & & & & \\
\hline 8 & \begin{tabular}{|l} 
Social \\
Science \\
Education
\end{tabular} & $0.0720^{*}$ & $0.0946 *$ & $0.0741^{*}$ & 0.0160 & 0.0058 & $-0.2996 *$ & -0.0296 & 1 & & & & & & & & & & & \\
\hline 9 & \begin{tabular}{|l|} 
Engineering \\
Degree
\end{tabular} & -0.0501 & $0.1706 *$ & 0.0155 & 0.0074 & -0.0204 & 0.0605 & $-0.1456 *$ & $-0.1387^{*}$ & 1 & & & & & & & & & & \\
\hline 10 & $\begin{array}{l}\text { Professional } \\
\text { Training } \\
\end{array}$ & 0.0350 & 0.0627 & -0.0218 & -0.0132 & -0.0347 & -0.0317 & $0.0799 *$ & $0.0926^{*}$ & $0.0639 *$ & 1 & & & & & & & & & \\
\hline 11 & \begin{tabular}{|l|} 
Central \\
Government \\
Experience \\
\end{tabular} & $0.0872^{*}$ & 0.0513 & 0.0226 & $0.1152^{*}$ & $0.0718^{*}$ & $-0.0824^{*}$ & -0.0225 & $0.3291^{*}$ & 0.0149 & 0.0996* & 1 & & & & & & & & \\
\hline 12 & \begin{tabular}{|l|} 
Private \\
Sector \\
Experience
\end{tabular} & 0.0295 & 0.0686 & -0.0349 & 0.0026 & -0.0110 & 0.0075 & $-0.0693 *$ & 0.0065 & $0.2106 *$ & $0.1169 *$ & $0.0917 *$ & 1 & & & & & & & \\
\hline 13 & \begin{tabular}{|l|}
$\#$ \\
Municipalitie \\
s previously \\
worked in \\
\end{tabular} & 0.0281 & 0.0331 & $-0.1528^{*}$ & $-0.0862^{*}$ & -0.0469 & $0.0717^{*}$ & 0.0419 & -0.0444 & $-0.1007^{*}$ & 0.0555 & $-0.1573^{*}$ & -0.0196 & 1 & & & & & & \\
\hline 14 & $\begin{array}{l}\text { Managemen } \\
\mathrm{t} \text { Experience }\end{array}$ & $-0.0741^{*}$ & $0.1084^{*}$ & -0.0114 & -0.0241 & $-0.0652^{*}$ & 0.0486 & $-0.1037^{*}$ & $0.1623^{*}$ & 0.0525 & $0.2794 *$ & 0.0322 & $0.0940^{*}$ & $0.1671^{*}$ & 1 & & & & & \\
\hline 15 & Tenure & 0.0206 & 0.0375 & 0.0117 & -0.0114 & -0.0322 & $0.4347^{*}$ & $-0.1516^{*}$ & -0.0666 & 0.0427 & -0.0338 & -0.0620 & -0.0261 & $-0.1202^{*}$ & 0.0242 & 1 & & & & \\
\hline 16 & \begin{tabular}{|l|} 
City \\
Manager \\
\end{tabular} & $0.2271^{*}$ & $0.3262^{*}$ & $-0.1008^{*}$ & -0.0112 & 0.0192 & 0.0237 & $-0.1514^{*}$ & $0.2571^{*}$ & $-0.0610 *$ & $0.0614^{*}$ & $0.0753^{*}$ & 0.0330 & $0.1274 *$ & $0.1565^{*}$ & 0.0035 & 1 & & & \\
\hline 17 & \begin{tabular}{|l|} 
Sector \\
Manager \\
\end{tabular} & -0.0172 & $0.1719 *$ & 0.0030 & -0.0016 & -0.0242 & -0.0278 & -0.0498 & $0.2513^{*}$ & $0.0831^{*}$ & $0.2224^{*}$ & $0.1998^{*}$ & $0.0749^{*}$ & 0.0226 & $0.2854^{*}$ & $0.0685 *$ & $-0.1936^{*}$ & 1 & & \\
\hline 18 & \begin{tabular}{|l|}
$\#$ \\
Subordinate \\
$\mathrm{s}$
\end{tabular} & 0.0992* & $0.2220^{*}$ & $0.2986 *$ & -0.0102 & -0.0253 & $-0.0818^{*}$ & -0.0678 & $0.1808^{*}$ & $-0.1471^{*}$ & 0.0264 & 0.0392 & -0.0367 & 0.0591 & $0.0930 *$ & -0.0497 & $0.3692^{*}$ & 0.0266 & 1 & \\
\hline 19 & $\begin{array}{l}\text { Organization } \\
\text { al Innovation } \\
\text { Index }\end{array}$ & $0.1281^{*}$ & $0.2063 *$ & $\mid 0.1647^{*}$ & 0.0681 & -0.0676 & 0.0365 & 0.0055 & 0.0512 & -0.0035 & $0.1001 *$ & 0.0422 & 0.0262 & -0.0019 & $0.1338^{*}$ & 0.0182 & $0.1081^{*}$ & $0.1337^{*}$ & $0.1399 *$ & 1 \\
\hline
\end{tabular}

